\title{
Patient and Public Involvement in Health Economics and Outcomes Research
}

\author{
Paula K. Lorgelly ${ }^{1}$ (1)
}

Accepted: 28 February 2021 / Published online: 17 March 2021

(c) The Author(s), under exclusive licence to Springer Nature Switzerland AG 2021

The disability movement first coined the phrase "Nothing about us without us" in the 1990s [1]. This followed the consumerist movement in the 1980 s where patients and the public were asked to provide feedback to understand if health care systems were meeting service users' needs (akin to customer satisfaction) [2]. Patients and the public then began to be involved in health service design and delivery decisions; for example, in the UK National Health Service (NHS) it is a statutory requirement to involve the public in planning and operational decisions about services. Mirroring this, public and patient involvement (PPI) in health research has grown to be the norm [2], and in many countries (including the UK, The Netherlands, Canada, Australia, and the US), PPI is a requirement for research funding. In the UK, INVOLVE (part of and funded by the National Institute of Health Research [NIHR]) defines PPI as actively working in partnership with patients and members of the public to plan, manage, design, and carry out research; it is research being carried out 'with' or 'by' members of the public rather than 'to', 'about' or 'for' them [3].

Much has been written on the broader concept of PPI $[4,5]$, methods for PPI [6, 7], and evaluating PPI [8-10]. The role of PPI in health economics and outcomes research (HEOR) is a fledging area, perhaps because HEOR often plays a supportive role in clinical trials or other health service research. Previous research has considered the role of PPI in health technology assessment, in terms of methodologies for including PPI and the public and patients in a decision-making role [11-13]. There is even published health economics research that analysed whether PPI delivers value and whether the potential benefits are greater than the costs [14].

Paula K. Lorgelly

p.lorgelly@ucl.ac.uk

1 Department of Applied Health Research, University College London, London, UK
Despite this, more research that specifically focuses on PPI in HEOR is warranted. A recent paper on the knowledge of PPI among health economists in Ireland [15] found gaps in the knowledge base, arguing that PPI was challenging due to a lack of time, resources, and the appropriate skills. That paper called for more education and training to support a greater use of PPI in health economics research. This themed issue specifically addresses that request by showcasing how the HEOR discipline is engaging with patients and/or the public - beyond their recruitment as research subjects-so they are active research partners and collaborators, including as co-investigators and co-authors.

This themed issue includes eight papers that highlight innovative ways HEOR researchers have engaged patients and/or the public; projects that have trained patients/the public in HEOR and those that have educated HEOR researchers on the patient perspective; and research that quantifies the value-added patient/public engagement on the impact of the project and/or programme of research. It includes research undertaken in Canada [16], the US [17, 18] and the UK [19-22], across a range of HEOR areas: outcomes research [17, 19], preference elicitation [16, 21], decision analytic modelling [22], and value assessment [18], including a general perspective of principles to improve patient involvement in HEOR [20]. A highlight of the themed issue is a commentary by a patient partner [23]; this provides a unique reflection of the experience of the patient as a partner in the research process.

I hope that this themed issue provides a useful go-to guide for HEOR researchers who want to engage and involve the public and patients in their research. The expertise and enquiry of patients and the public will ultimately benefit the HEOR discipline, ensuring we answer questions of importance, respectfully, and thereby ensuring our research delivers impact to those who need it. Recently, there has been a wider call for a more critical research agenda on the public involvement in research [24]. I look forward to researchers 
in HEOR and their PPI partners contributing to that agenda, and this themed issue being a harbinger.

\section{Declarations}

Conflicts of interest Paula K. Lorgelly declares no conflicts of interest.

\section{References}

1. Charlton JI. Nothing about us without us: disability oppression and empowerment. Oakland: University of California Press; 2000.

2. Wilson P, Mathie E, Keenan J, McNeilly E, Goodman C, Howe A, et al. ReseArch with Patient and Public invOlvement: a Realis T evaluation - the RAPPORT study. Health Serv Deliv Res 2015;3(38). http://journalslibrary.nihr.ac.uk/hsdr/hsdr03380.

3. INVOLVE. What is public involvement in research. 2021. https:// www.invo.org.uk/resource-centre/resource-for-researchers/. Accessed 29 Jan 2021.

4. Bagley HJ, Short H, Harman NL, Hickey HR, Gamble CL, Woolfall $\mathrm{K}$, et al. A patient and public involvement (PPI) toolkit for meaningful and flexible involvement in clinical trials-a work in progress. Res InvolvEngagem. 2016;2(1):1-14. https://doi.org/10. 1186/s40900-016-0029-8.

5. Jackson T, Pinnock H, Liew SM, Horne E, Ehrlich E, Fulton O, et al. Patient and public involvement in research: from tokenistic box ticking to valued team members. BMC Med. 2020;18(1):79. https://doi.org/10.1186/s12916-020-01544-7.

6. Gillard S, Simons L, Turner K, Lucock M, Edwards C. Patient and public involvement in the coproduction of knowledge: reflection on the analysis of qualitative data in a mental health study. Qual Health Res. 2012;22(8):1126-37.

7. Gray-Burrows KA, Willis TA, Foy R, Rathfelder M, Bland P, Chin $\mathrm{A}$, et al. Role of patient and public involvement in implementation research: a consensus study. BMJ Qual Saf. 2018;27(10):858-64. https://qualitysafety.bmj.com/content/qhc/27/10/858.full.pdf.

8. Blackburn S, McLachlan S, Jowett S, Kinghorn P, Gill P, Higginbottom $\mathrm{A}$, et al. The extent, quality and impact of patient and public involvement in primary care research: a mixed methods study. Res InvolvEngagem. 2018;4(1):16. https://doi.org/10.1186/ s40900-018-0100-8.

9. Boivin A, Richards T, Forsythe L, Grégoire A, L'Espérance A, Abelson $\mathrm{J}$, et al. Evaluating patient and public involvement in research. Br Med J. 2018;363:k514. https://www.bmj.com/conte nt/363/bmj.k5147.

10. Wilson P, Mathie E, Poland F, Keenan J, Howe A, Munday D, et al. How embedded is public involvement in mainstream health research in England a decade after policy implementation? A realist evaluation. J Health Serv Res Policy. 2018;23(2):98-106. https://doi.org/10.1177/1355819617750688.

11. Abelson J, Wagner F, DeJean D, Boesveld S, Gauvin F-P, Bean S, et al. Public and patient involvement in health technology assessment: a framework for action. Int J Technol Assess Health Care. 2016;32(4):256-64. https://doi.org/10.1017/S0266462316000362.
12. Barham L. Public and patient involvement at the UK National Institute for Health and Clinical Excellence. Patient Patient Center Outcomes Res. 2011;4(1):1-10.

13. Facey KM, Hansen HP, Single AN, editors. Patient involvement in health technology assessment. Singapore: Springer; 2017.

14. Pizzo E, Doyle C, Matthews R, Barlow J. Patient and public involvement: how much do we spend and what are the benefits? Health Expect. 2015;18(6):1918-26. https://doi.org/10.1111/hex. 12204.

15. O'Shea E, Ogbebor F, Queally M, Murphy E. Knowledge of public patient involvement among health economists in Ireland: a baseline audit. HRB Open Res. 2019;2(4):4. https://hrbopenres earch.org/articles/2-4.

16. Aguiar M, Harrison M, Munro S, Burch T, Kaal KJ, Hudson M, et al. Designing discrete choice experiments using a patient-oriented approach. Patient Patient Center Outcomes Res. 2020;5:6. https://doi.org/10.1007/s40271-020-00431-w.

17. Clearfield E, Tambor E, Janssen EM, Messner DA. Increasing the patient-centeredness of health economics and outcomes research through patient engagement in core outcome set development. Patient Patient Center Outcomes Res. 2020. https://doi.org/10. 1007/s40271-020-00424-9.

18. Linthicum MT, dosReis S, Slejko JF, Mattingly TJ, Bright JL. The importance of collaboration in pursuit of patient-centered value assessment. Patient Patient Center Outcomes Res. 2020. https:// doi.org/10.1007/s40271-020-00446-3.

19. Al-Janabi H, Coles J, Copping J, Dhanji N, McLoughlin C, Murphy $\mathrm{J}$, et al. Patient and public involvement (PPI) in health economics methodology research: reflections and recommendations. Patient Patient Center Outcomes Res. 2020. https://doi.org/10. 1007/s40271-020-00445-4.

20. Hawton A, Boddy K, Kandiyali R, Tatnell L, Gibson A, Goodwin E. Involving patients in health economics research: "The PACTS Principles.” Patient Patient Center Outcomes Res. 2020. https:// doi.org/10.1007/s40271-020-00461-4.

21. Shields GE, Brown L, Wells A, Capobianco L, Vass C. Utilising patient and public involvement in stated preference research in health: learning from the existing literature and a case study. Patient Patient Center Outcomes Res. 2020. https://doi.org/10. 1007/s40271-020-00439-2.

22. Staniszewska S, Hill EM, Grant R, Grove P, Porter J, Shiri T, et al. Developing a framework for public involvement in mathematical and economic modelling: bringing new dynamism to vaccination policy recommendations. Patient Patient Center Outcomes Res. 2021. https://doi.org/10.1007/s40271-020-00476-x.

23. Burch T. Patient commentary: added value and validity to research outcomes through thoughtful multifaceted patient-oriented research. Patient Patient Center Outcomes Res. 2020. https://doi. org/10.1007/s40271-020-00432-9.

24. Russell J, Fudge N, Greenhalgh T. The impact of public involvement in health research: what are we measuring? Why are we measuring it? Should we stop measuring it? Res InvolvemEngagem. 2020;6(1):63. https://doi.org/10.1186/ s40900-020-00239-w. 